\title{
Pseudomonas syringae pv. syringae によるライラック枝枯細菌病
} 鍵渡 徳次*.夏秋 啓子* ・藤井 溥* - 向 秀夫*

\author{
Tokuji Kagiwata*, Keiko T. Natsuaki*, Hiroshi Fujir* and Hideo Mukoo*: \\ Bacterial Blight of Lilac Caused by Pseudomonas syringae pv. syringae
}

\begin{abstract}
Bacterial blight of lilac (Syringa vulgaris L.) was found in Nagano Pref., Japan. The disease first appears on shoot as water-soaked small spot. Those spots rapidly enlarge in size and become sunken, blackish and elliptical lesions. The lesions usually elongate longitudinally to form irregular-shaped stripes. Affected young shoots bend over at the lesions, wither and often die. The pathogenic bacterial isolates were identified as Pseudomonas syringae pv. syringae van Hall 1902 from the results of pathogenicity and bateriological tests.
\end{abstract}

Key words: lilac, bacterial blight, Pseudomonas syringae pv. syringae.

1982 年春, 長野県小布施町で, ライラック (Syringa vulgaris L.) に枝枯性病害が多発した。本病はPseudomonas syringae pv. syringae による新病害であること が判明したので報告する。な和本研究の概要はすでに 報告 ${ }^{1,2)}$ した。

長野県では 1973 年に, オランダからライラック苗 木を導入し，3 ha に栽植したが，2,3 年後より枝に病 斑が散見されはじめ, 1980 年ごろにはその被害が目だ つようになり，急速に増加して今回の多発を見るにい たった。発生は 1.5 ha に見られたが, 最も被害が多 かった品種はマダム・フローレント・ステップマンで あり,ついでグリム・ローズ・イエロー, キャサリン・ ハバメイヤー, マダム・ルモアンスなどであった。ま たスーベニア・デ・ルイス・スペス, チャールス・ジ ョリー, ェースター・スタレー, ミッシェル・ベシネ ール, チャールス・レックス, ベルド・ナンシー, 白 竜などにも軽症ながら被害が見られた。

病徵 新芽展開時より 5 月中下旬にわたり, 主とし て新梢の節間部に発生する。はじめ節間に暗褐色水浸 状の小斑点を生じ，急速に拡大し，長だ円形，黒褐色 の陷没した病斑となる。さらに病勢が進さと，大型不 整形の条斑を形成し，最後には枯死する(Fig. 1)。伸
長中の幼梢では病斑部より湾曲し，上部は萎らょう枯 死する。また新芽, 葉执よび花房にも発生し, 不整形 黒褐色の病斑を生じる。病原細菌は主として柔組織を 侵し, また導管内に侵入し, 上方の葉を発病させるこ とがある。

細菌の分離と接種試験 新鮮な病斑部より希釈平板 法により，容易に同一の集落形状を示す細菌が分離で きた。この細菌を野外のライラックに有傷（針）执よ び無傷 (塗布) 接種し, 自然状態に保った。有傷接種 では 2〜3 日後に, 葉执よび新梢の接種部を中心にし て，壊死斑が形成された。無傷接種では，葉には異状 がなかったが，新梢では 3〜4 日後に黒褐色の壊死斏 を形成し，7 日後には自然発生と同様な発病状態を示 した。しかし発病梢率はきわめて低かった。ウメ，ス モモ, ナシ, イボタ, クチナシ, キョウチクトウ, ウ ンシュウミカンの葉と新梢拉よびレモン, マンゴー, リンゴの果実に有傷接種したところ, ウンシュウミカ ン, レモンには異状がなく，それ以外の植物は，接種 部に壊死斑を形成した。またライラック，ナシキョ ウチクトウでは，葉脈拉よびその周辺組織に大型不整 形の壊死斑を形成した。

本細菌の細菌学的性状 細菌学的性状は, 主として

\footnotetext{
* 東京農業大学 Tokyo University of Agriculture, Sakuragaoka, Setagaya-ku, Tokyo 156, Japan 1）鍵渡徳次・今村昭二・藤井 溥 - 向 秀夫 (1983). 日植病報 $49: 128-129$ (講要). 2) 鍵渡徳次 ・ 夏秋啓子・藤井 溥.向 秀夫 (1984). 同上 $50: 422$ (講要).
} 
Table 1. Bacteriological properties of lilac isolates and $P$. syringae pv. syringae

\begin{tabular}{|c|c|c|c|c|c|}
\hline \multirow{2}{*}{ Characters } & \multirow{2}{*}{$\begin{array}{c}\text { Lilac } \\
\text { isolates }\end{array}$} & \multicolumn{4}{|c|}{ P. syringae pv. syringae } \\
\hline & & Bryan & Clara & Tominaga & Bradbury \\
\hline Gram reaction & - & - & - & - & - \\
\hline No. of flagella & $1-4$ & $1-5$ & $1-2$ & $1-3$ & $>1$ \\
\hline Fluorescent pigment & + & + & + & + & + \\
\hline Pyocyanine & - & & & - & - \\
\hline Oxidase reaction & - & & & - & - \\
\hline O-F test & $\mathrm{O}$ & & & $\mathrm{O}$ & $\mathrm{O}$ \\
\hline Uschinsky's solution & + & + & + & $W^{a)}$ & \\
\hline Fermi's solution & + & + & & $\mathrm{W}$ & \\
\hline Cohn's solution & W & $\mathrm{W}$ & & - & \\
\hline Arginine dihydrolase & - & & & - & - \\
\hline Nitrate reduction & - & W & - & - & - \\
\hline Gluconate oxidation & - & & & - & \\
\hline \multicolumn{6}{|l|}{ Hydrolysis of: } \\
\hline Gelatin & + & + & + & + & + \\
\hline Aesculin & + & & & + & + \\
\hline Arbutin & + & & & $\mathrm{W}$ & + \\
\hline Starch & $\mathrm{W}$ & W & & W & - \\
\hline Margarine & - & & & - & \\
\hline \multicolumn{6}{|l|}{ Production of: } \\
\hline $\mathrm{H}_{2} \mathrm{~S}$ & - & - & - & - & \\
\hline Indole & - & - & - & - & \\
\hline Ammonia & + & + & + & + & \\
\hline \multicolumn{6}{|l|}{ Utilization of: } \\
\hline Xylose & + & & + & + & + \\
\hline Glucose & + & + & + & + & + \\
\hline Galactose & + & + & + & + & \\
\hline Sucrose & + & + & + & + & \\
\hline Maltose & - & - & - & - & \\
\hline Lactose & - & - & - & - & \\
\hline Trehalose & - & & & & - \\
\hline Glycerol & + & + & + & + & \\
\hline Sorbitol & + & & & + & + \\
\hline Mannitol & + & + & + & + & + \\
\hline Inositol & + & & & & + \\
\hline DL-Tartrate & - & & - & - & - \\
\hline Succinate & + & & + & & + \\
\hline Levan production & + & & & + & + \\
\hline Potato soft rot & - & & & - & \\
\hline Tobacco hypersensitive reaction & + & & & - & + \\
\hline Growth at $41 \mathrm{C}$ & - & - & & - & - \\
\hline
\end{tabular}

a) W: feeble growth or weak reaction.

富永 ${ }^{3)}$ の方法によって実験した。本細菌はグラム陰 性, 好気性, 桿状, $1 \sim 4$ 本の極毛を有し, 運動性で芽 胞, 萊膜, ポリー $\beta$ ーヒドロキシ酪酸顆粒は観察されず, 普通寒天培地上では，48 時間で径 $1 \mathrm{~mm}$ の集落を形 成し，集落は乳白色，円形，全縁，中高，湿光を帯び
平滑，半透明で牛酪質であった。またラフ型集落を形 成する菌株も見られた。ブイヨン，ペプトン水では発 育良好で混濁し, 沈殿を生じたが皮膜は形成しなかっ た。ウシンスキー氏液, フェルミ氏液には良好に発育 したが，コーン氏液には不良であった。グルコースを

3）富永時任 (1971). 農技研報 C 25 : 205-306. 


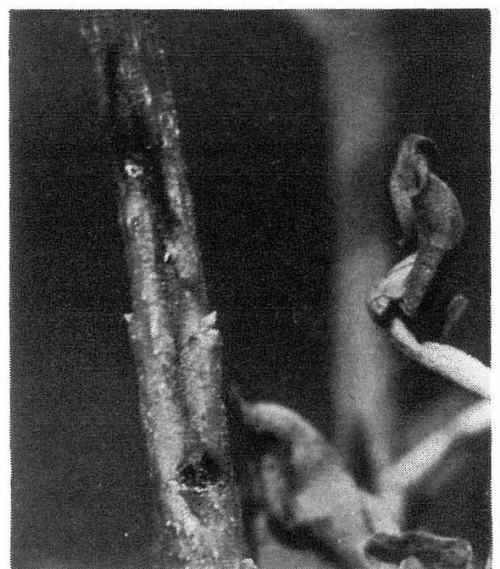

Fig, 1. Irregular-shaped and striped lesion on lilac shoot.

酸化的に分解し, 緑色蛍光色素打よびレバンを産生し たが、ピオシアニンは産生せず, リトマス牛乳は還元 し消化した。オキシダーゼ，アルギニンジヒドロラー ゼ, フェニルアラニン・デアミナーゼ, レシチナーゼ, チロシナーゼの各活性, 硝酸塩の還元, 硝酸呼吸, 硫 化水素㧺よびインドールの産生, グルコン酸の酸化, マーガリンの加水分解, VP 反応, MR 試験, ジャガ イモ塊茎の腐敗はそれぞれ陰性であった。カタラーゼ 活性, アンモニアの産生, スクロースより還元物質の 生成, ゼラチン, エスクリン, アルブチン, ツイーン 80 の加水分解, タバ二葉の過敏感反応はそれぞれ陽 性であった。デンプンの加水分解和よびチトクロムオ キシダーゼ活性は弱陽性を示した。またキシロース, アラビノース, グルコース, フラクトース, ガラクト 一ス, マンノース, スクロース, ラフィノース, グリ セリン，ソルビトール，マンニトール，イノシトール， マロン酸, クエン酸, コハク酸を利用し, ラムノース, セロビオース，マルトース，ラクトース，トレハロー
ス，デキストリン，デンプン，イヌリン，アドニトー ル，ズルシトール，サリシン，エスクリン，DL-酒石 酸は利用しなかった。アルギニン,バリンの利用は弱 陽性を示した。発育適温は $27 \mathrm{C}, 41 \mathrm{C} て ゙ は$ 発育せ

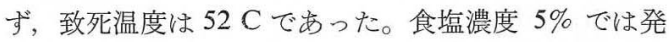
育しなかった。各項目の試験には 120 菌株（少数の項 月については 20 菌株）を用いたが，菌株間には差異 がなく，性状がまったく同一の細菌と判断された。

本細菌の同定 グラム陰性, 極毛桿菌, 好気性で白 色集落を形成し, 糖を酸化的飞分解することから Pseudomonas 属であり, Lelliott $ら^{4)}$ の LOPAT 試験 が，+ー-ー+，グルコン酸の酸化，マーガリンの加 水分解, 硝酸還元が陰性で㐫り, スクロースから酸の 産生, ゼラチン技よびェスクリンの加水分解が陽性で あるので，P. syringae pv. syringae 飞該当する。おた Bryan ${ }^{5)}$, Clara ${ }^{6)}$, 富永 ${ }^{32}$ が記載した P. syringae pv. syringae の特性なども，本細菌とほぼ一致した。Dye 57) は Doudoroff $5^{8)}$ が P. syringae 飞含めた一群の 細菌を，病原性によって細分したが，Bradbury9) は Doudoroff ら ${ }^{8)}$ が記載した P. syringae の特性の添 に, さらに配糖体の加水分解能や炭素源の利用性など を追加して，pv. syringae の特性を記載した。本細菌 はとれらの記載ともほぼ一致した (Table 1)。

以上のよらに, 本細菌は病原性拉よび細菌学的性状 のいずれからも, Pseudomonas syringae pv. syringae van Hall 1902 と同定された。病名はライラック枝枯 細菌病 Bacterial blight of liac とした。な捄供試した 本細菌の L 177-179 菌株は, 農林水産省農業環境技術 研究所飞預託され，NIAES 2085-2087 として登録さ れた。

報告するにあたり，ご協力をいただいた元長野県病 害虫専門技術員今村昭二氏に感謝する。

(昭和 63 年 11 月 7 日受理)

4) Lelliott, R.A., Billing, E. and Hayward, A.C. (1966). J. appl. Bact. 29: 470-489. 5) Bryan, M.K. (1928). J. Agric. Res. 36: 225-235. 6) Clara, F.M. (1934). Cornell Univ. Agric. Exp. Sta. Memoir 159: 1-36. 7) Dye, D.W., Bradbury, J.F., Goto, M., Hayward, A.C., Lelliott, R.A. and Schroth, M. N. (1980). Rev. Plant Pathol. 59: 153-168. 8) Doudoroff, M. and Palleroni, N.J. (1974). In Bergey's Manual of Determinative Bacteriology (Buchanan, R.E. and Gibbons, N.E. eds.). 8th ed. Williams and Wilkins Co., Baltimore. pp. 217-243. 9) Bradbury, J.F. (1986). Guide to Plant Pathogenic Bacteria. CAB International Mycological Institute, Farnham Royal. pp. 175-177. 